\title{
Decentralization as a Tool for Ethnic Diversity Accommodation: A Conceptual Analysis
}

\author{
Mohammad Agus Yusoff ${ }^{1}$, Athambawa Sarjoon ${ }^{1,2} \&$ Mat Ali Hassan $^{3}$ \\ ${ }^{1}$ School of History, Politics and Strategic Studies, Faculty of Social Sciences and Humanities, Universiti \\ Kebangsaan Malaysia, UKM Bangi 43600, Selangor, Malaysia \\ ${ }^{2}$ Department of Political Science, University of Peradeniya, Peradeniya 20400, Sri Lanka \\ ${ }^{3} \mathrm{PhD}$ Candidate, Faculty of Human Ecology, Universiti Putra Malaysia, 43450 UPM Serdang, Selangor, \\ Malaysia
}

Correspondence: Mohammad Agus Yusoff, School of History, Politics and Strategic Studies, Faculty of Social Sciences and Humanities, Universiti Kebangsaan Malaysia, UKM Bangi 43600, Selangor, Malaysia. Tel: 60-19-338-0962. E-mail: agus_ukm@yahoo.com

\author{
Received: December 3, 2015 Accepted: December 29, 2015 Online Published: February 28, 2016 \\ doi:10.5539/jpl.v9n1p55 \\ URL: http://dx.doi.org/10.5539/jpl.v9n1p55
}

\begin{abstract}
With the increase of ethnic conflicts and ethnic groups' mobilizations for ethno-nationalism to secure and share state power, the concept of decentralization has also been getting attention in ethnically plural countries, and many of them have taken advantages of adopting decentralization policies for the empowerment of diverse groups in their state cum nation-building process. Similarly, the requests and supports for the adaptation of different forms of decentralization as to accommodate number of political and administrative demands and claims emerging from different ethnic groups within a country has also increased in the recent past. This has induced the researcher and international actors to develop different definitions, interpretations, and objectives for decentralization on its ethnic diversity accommodation perspective. This paper attempted to conceptualize the decentralization as a tool for ethnic diversity accommodation through reviewing the existing literary definitions, explanations and with researchers' interpretive arguments. The finding reveals that decentralization initiatives, like other impacts, in number of ways, contributes to accommodate rights, interests, needs and claims of competing ethnic groups, especially of ethnic minorities and accommodate them within the larger political system and their local attachments. However, the success of this process highly depends on the mechanisms adopted for sharing powers and responsibilities; the nature, subject and decree of decentralized power; and the willingness of authorities to allow the groups to exercise those powers, with other factors.
\end{abstract}

Keywords: decentralization, ethnic diversity, minority claims, ethnic accommodation

\section{Introduction}

Decentralization has received a popular concern among academics, statesman, policy-makers and international mediators and donors as a concept for accommodating the diverse interests and demands emerging from different groups of people. Different types and forms of decentralization are identified by the researchers and international agencies as useful devises in making state closer to the public in providing the essential services efficiently and effectively and resolve number of problems associated with delivering essential services. Also, decentralization mechanisms make people monitoring and questioning government institutions and enable government authorities to resolve or manage conflicts and claims emerging among different groups advocating more autonomy, ownership and resources as to make them empowered and autonomous. Therefore, decentralization has been the major focus of many governments not only in developing world, but also in the well-developed world intended to resolve group conflicts and to build ethnic and social cohesion in many heterogeneous societies. As Faguet (2013) emphasized, decentralization has been one of the most widespread and influential policy trends of the present generation.

Decentralization has become intrinsically bound with ethnic politics in many plural countries especially emerged with the end of colonial rule and the breakup of communist block around the world. At the end of Second World War, many plural nations have seen a rise in ethnically motivated discrimination that led to conflict, violence and civil war. The ultimate result was that many ethnically bounded groups mobilized to justify and advocate their 
claims to increase political and other kinds of autonomy being made on their behalf. The ethnic entrepreneurial behaviors of political leaders have also induced the advocacy for greater autonomy for ethnically bounded groups. This ethnic groups identity became proved as a powerful political weapon for minorities when many governments paid due concerns to accommodate their demand and claims through decentralization policy reforms. Many ethnic groups whether they were able to solidify their ethnic identity or ethnic consciousness through physical boundaries within the state or even though transcend boundaries, but shown their strong ethnic belonging and justification of their demands, were able to achieve political powers or made part of ethnically conceived autonomous arrangements through decentralizing central power. Conversely, there were also disagreements among members of some specific ethnic groups as to where the boundaries of ethnicity go beyond the limit of those local autonomous or power-sharing units therefore not all were included or become part of that unit because ethnicity often has a fluid quality that transcend boundaries conceived on state map. This led those ethnic groups further mobilize and claim toward more decentralized power. Therefore, the decentralization became a popular concept in countries dealing with competing ethnic groups for more power and regional (local) autonomy.

On the above backdrop, this paper tries to conceptualize decentralization as a useful devise for accommodate rights, needs, claims and demands emerging among diverse ethnic groups. The major objectives of this paper is to identify the ways that decentralization take in accommodating concerns and priorities of diverse population, especially of minority groups in terms of ethnic, religious and regional differences within the larger political entity. This paper is divided into five major parts. The first part introduces the paper in brief followed by the review of the trends and major themes of existing literatures on decentralization as a tool for accommodating the diverse interests and claims of groups. The next section briefly defines decentralization and its dimensions. The fourth part of the article conceptualizes the ethnic diversity accommodative perspective of decentralization from different angles. In this part an extensive analysis is made on how decentralization initiatives contribute to accommodate rights and interests of different groups, especially of minorities within the larger political system and within their local entity, followed by a conclusion. Since this paper is a conceptual analysis one, the paper adopted only the secondary data available in the existing literature. Further, even though there are many driving forces and motivations behind the decentralization initiatives, but this paper mainly conceptualize the ethnic diversity accommodate perspective of decentralization. Therefore, an extensive analysis is made to identify how decentralization contributes to empower diverse ethnic groups, mostly minorities in political power-sharing at center, regional and local governance, ethnic groups partnership in local development, resolve issues and conflict emerge between groups, and the accommodation of different groups in post-civil war and post-conflict democratization process.

\section{Reviewing the Trends of Decentralization Literature}

The literature produces ambiguous and time contradictory findings about the impacts of decentralization on accommodating the rights, interests and expectation of diverse ethnic groups within a state or a geographically demarcated area or a unit of administration and governance such as region, district, zones and divisions. Decentralization can be defined as a process of sharing central state power to sub-national units of governance at different levels to increase the capacity of political and administrative decision-making in order to localize the provisions of delivering public goods and services and strengthen development initiatives while accommodating the interests of diverse groups in these affairs. From 1950s, decentralization has been a popular concept with number of thematic motivations such as such as, political independence, regional and local development, good governance, improved service delivery, conflict management, ethnic accommodation and so on (Grasa \& Gamps, 2009; Linder, 2009; Brancati, 2006; Monteux, 2006; Schou \& Haug, 2005; Scott, 1996). It has been identified by scholars as a "fashion in development administration" (Conyers, 2006; Conyers, 1983; Scot, 1996). From the new millennium, number of countries have been adopting decentralization policies or at least attempting to adopt reforms toward decentralization. As Grasa and Camps (2009) indicates, decentralization has quietly become a fashion for the last two decades.

Within the domain of political science and public administration, many studies have focused decentralization mainly on its role in supporting and strengthening democratization. This kind of researches pays concern more on political perspectives of decentralization, especially of devolution of power and resources from higher level of political system to elected bodies at local levels. Some studies pay economic and development perspectives of decentralization. These researches focus on the role of decentralization policies on local development, poverty reduction or alleviation, local capacity to initiate or manage development projects, and on the participation of local groups (including women, minorities) in development initiatives. These studies identify decentralization promise for reducing poverty which always arises from inequalities between regions or localities, and between different groups.

However, most of the existing literatures on decentralization have paid little concern on how these forms of 
decentralization policies accommodate the concerns and interest of diverse groups, especially of minorities in terms of ethnicity and religion living at local level. In fact, all forms of decentralization have a conflict reduction and ethnic cohesion rule in multi-ethnic societies, by consenting different groups to involve in the political decision-making and the administration of local affairs including the development and empowerment of groups and their areas. Under decentralized system, minorities and regionally concentrated groups will also be treated equally and empowered with political, administrative and financial powers in their local affairs.

Since this paper conceptualizes decentralization as a device to accommodate the rights, and interests of diverse population, especially of minorities in terms of ethnic and religious differences who are discriminated in political power sharing, and development initiatives through number of projects and policies in terms of state cum nation-building, national integration, an extensive analysis of the concepts of decentralization, and its forms are important for the clear understanding of the above perspective of decentralization.

\section{Defining Decentralization and its Dimensions}

Decentralization, like many concepts in social science, is more complex to define. In political science and public administration perspectives, decentralization can be defined as procedure or a tool for sharing powers and divide responsibilities among central government institutions and locally established political and administrative bodies with the objective improving public service delivery, induce economic and regional development, and to empower the political and other rights of different groups formed on ethnicity, language, region, religion etc. Various scholars in political science, public administration and development studies have defined decentralization as transference of authority and responsibility from center to peripheries; delegation of decision-making powers to locally established governance units; placement of authority with responsibility; removal of number of functions from the center and place them in the peripheries (Linder, 2009; Cheema \& Rondinelli, 2007; Brancati, 2006; Kassahun \& Tengegne, 2004; Conyers, 1999). Both Cheema and Rondinelli, simply define decentralization as the transfer of authority, responsibility, and resources - through de-concentration, delegation, or devolution-from the center to lover level of administration (Cheema \& Rondinelli, 2007; Rondinelli et al., 1989). According to Bolleyer and Tharlarson (2012), decentralization is the removal of core resources from the center to place them at lower levels of a multi-tiered governance system, whether these resources are fiscal, jurisdictional, or administrative. Lyon (2013:82) defines decentralization as a process by which the relations of central and locals become restructured within a unitary state.

The above definitions of decentralization point out some important aspects/natures of decentralization as noted bellows:

a) Decentralization is a process of transfer or share powers and authorities of institutions and officers of central government to the sub-national governance units.

b) The nature of transferred powers or authority may be in different form (example: allocated, delegated, devolved, de-concentrated or shared).

c) The nature of functions expected through decentralization also may vary (example: monitoring, controlling, administering, managing, planning, plan implementing).

d) In the process of decentralization, it is important to form, create or establish regional or local level government institutions in order to strengthen the local capacity to fulfill the expected outcome through decentralization initiatives. These institutions may differ in terms of the nature of decentralized powers they gaine and expected objectives of the functions and services they perform (example: regional councils or centers, districts, local government bodies, service center or units, supply centers and branches of central departments etc.).

e) Variety of subject area can be expected to be improved through decentralization (example: public service delivery, democracy building, regional and local development, women and minority empowerment, good governance, local participation etc.)

f) The dimensions of decentralized powers and authorities also vary (example: political, administrative and fiscal).

g) The success of fulfilling the expected objects and outcomes through decentralization depends on some conditional factors (example: clearly defined constitutional and legal framework, policy guidelines, institutional capacity, monitoring mechanisms, efficient, and commitment of staff, public participation and auditing etc.).

The success of decentralization initiatives depends, however, on the contexts of implementing countries, the design and dimensions of decentralization initiatives, and the governing principles of implementing process and institutions. 


\subsection{Types of Decentralization}

Decentralization may take different types but scholars identified it as three fundamental types which have different objectives, degree and means of decentralization of power. They are political, fiscal and administrative.

\subsubsection{Political [or Democratic] Decentralization}

Political decentralization is associated with power-sharing through the recognition of federal principles, autonomy and the like. It reflects whether subnational governments are directly elected, and thus share in the political functions of governance (Faust \& Harbers, 2011:56). This kind of decentralization normally refers to situations where political power and authority has been partially transferred to sub-national levels of government. The most obvious manifestations of this type of decentralization are elected and empowered sub-national forms of governments ranging from village councils to state-level bodies. Devolution is considered as one of the best form of political decentralization. Political decentralization aims to give citizens or their elected representatives more power in public decision-making. It also increases the participation of citizens and civil society in their selection of governmental representatives and in political decision-making.

\subsubsection{Fiscal [or Financial] Decentralization}

In general, fiscal decentralization denotes the transfer of power by the central government to local level political and administrative institutions handling financial matters under the purview of its authorities. This transferred power can empower these local institutions for rising of funds and collecting taxes and spend them for local level development and other needs. Therefore, fiscal decentralization entails the transfer of powers to raise (tax) and retain (spend) financial resources to fulfill assigned responsibilities (Cabral, 2011). The main expectation of the fiscal decentralization is that the localities should rely less on financial transfers from the central or regional governments and more depend on sufficient funds and creative accounting in order to fill the gaps in the local budgets.

\subsubsection{Administrative [or Institutional] Decentralization}

In general, administrative decentralization can be defined as transfer of authority from a higher level of government to a lower; delegation of decision-making; placement of authority with responsibility; removal of functions from center to the periphery; According to Ayenew (1998: 1), administrative decentralization involves the sharing of responsibility and authority between headquarters and the field offices. The functions and authority are centrally delegated as a matter of administrative expediency and can be revoked by the center when circumstances warrant with the objective of efficiency in government through centralized allocation of resources, including manpower and finance. Since, administrative decentralization is often seen as part of civil service reform it requires the creation or development of administrative bodies, systems and mechanisms, at local or intergovernmental level, to manage and support the decentralization process (Smoke, 2003).

\subsection{Forms of Decentralization}

Many governments in developing countries have attempted to improve variety of decentralization policies with different thematic motivations. There are some fundamental forms of decentralization. The existing literatures have categorized decentralization generally in three terms: Devolution, Delegation and De-concentration. A review of these terms (forms) is helpful to understand the concept clearly.

Devolution is a more extreme form of decentralization, refers to a situation in which the central government transfer authority and responsibilities for decision-making, finance and management to quasi-autonomous unit of governance at lower level largely outside the direct control of the central government, often through an electoral process which makes local governance unit directly accountable to local people (Cabral, 2011). The main objective of devolution is political, i.e. reshaping the political setting by redistributing power to increase the participation different groups in decision-making in the local affairs.

Delegation involves the transfer of power and responsibilities from the central government to local government or semi-autonomous organizations that are not wholly controlled by the central government, but are ultimately accountable to it, for making decisions and administration of public functions. Many developing countries utilizes this kind of decentralization practice in the creation of boards, authorities, corporations, special service districts, semi-autonomous school districts, regional development corporations, or special project implementation units or any other separate agencies for carrying out specific functions (Islam \& Fujitha, 2012:5).

De-concentration - sometimes referred as "bureaucratic decentralization" involves the transfer of administrative responsibilities or functions to subordinate units of government, often on some geographical basis. De-concentration entails the mere relocation of execution to the local level with decision-making power remaining 
at the center (Cabral, 2011:2). De-concentration is often considered as the weak form of decentralization and is used most frequently in unitary states. But, under de-concentration arrangement, the central government retains authority over field office, and exercises that authority through the hierarchical channels of the central government bureaucracy.

As viewed above, decentralization and its dimensions or forms seems to be very good means to strengthen democracy and good governance, especially at local level and being as an exclusive mechanism to accommodate interests of diverse groups, especially of ethno-regional and religious minorities within plural societies. The following part further analyzes how decentralization and its dimensions are being as supportive mechanism (or tool) to accommodate and empower the rights and interests of diverse groups including minorities.

\section{Decentralization as a Tool for Ethnic Groups Accommodation and Empowerment}

Rulers, policy-makers and scholars have also found decentralization as a tool for accommodating diverse ethnic groups in a larger political system where differences prevail in terms of socio-cultural, economic conditions and political differences and claiming for more autonomy and powers within and beyond the geographical limits of the groups live. It is noteworthy to emphasize that more than 90 percent of the sovereign states consist one or more different ethnic groups, especially of minorities of significant size.

In most of the developing countries, various groups, especially minorities have been mobilizing to defend their collective rights and interests and promote their collective demands for security, identity, status, economic opportunities, and political power, in competition, with other ethnic communities (mostly with majorities) in opposition to government policies and projects (Esman, 1997:527). Most of these policies and projects in these countries can be identifies as decentralization policies and in most of the occasions (cases) they have failed to address or accommodate the rights and interests (or needs) of the minority groups, or favored majorities. In many ethnically plural societies, conflicts emerge mostly in justifying decentralization of powers from center to periphery or regions, and local level units due to the lack of balance between the ethnic majorities and the ethnic minorities. Therefore, politicians, administrators, international actors, conflict mediators identify and advocate decentralization as mechanism or tools for accommodate rights, interests and needs of different ethnic groups mostly concentrated within a geographical boundary; and to resolve or mitigate the conflicts emerge among them.

Decentralization can be used for achieving number of objectives. Many experts found decentralization as a tool to mitigate ethnic tension, ethnic conflict and to incorporate the due rights, interests and needs of ethno-regional [minority] groups within political and administrative systems. Many theorists and practitioners argue that decentralization reforms and initiatives can be used to ease tensions among ethnic groups in post-war as well as post-conflict societies. By sharing powers with and devolving authority and responsibility to locally established political and administrative bodies, the central government may seem less threatening, and all ethnic groups and communities can run their own affairs independently and settle their grievances sing their own mechanism or without them most interference of central government (Brinkerhoff, 2005; Turner, 2006; Duncan, 2007; Siegle \& O’Mahony, 2009; Linder, 2009; Gjoni et al., 2010; Lyon, 2013).

Decentralized powers are thought to accommodate the interests and concerns of various distinct and separate cultural, political, religious, ethnic, or linguistic groups with the introduction of decentralization initiatives. The high degree of autonomy and self-rule offered to groups, especially of minorities may actually mark a turning point in the conflict and enhance national cohesion (Gjoni et al., 2010). The conflict-mitigating rationale of decentralization in ethnically diverse societies is that by ensuring diverse minority groups' participation and representation, it provides political and administrative channels, through which differences can be reconciled. The prospects for formal power within the national structure further represent an incentive for ethnic minorities' cooperation with the central government. The greater local control over the issues that affect the vast majority of citizen's daily routines, moreover, provides assurance to minority groups that their priority concerns will be considered in governance and administration.

In this way, decentralization is considered as a flexible institutional mechanism to accommodate the varied concerns and priorities of diverse populations within the limit of a state or a local government unit. The greater level of ethnic minority participation and their voice in the public sphere expected under decentralized system are also seen as stabilizing force in governance process in plural societies. Similarly, by establishing more layers of government administration, decentralized systems defuse competition (and fear) away from a single, winner-take all prize system (Siegle \& O’Mahony, 2009). Similarly, the sharing or handing over powers to local and regional level political administrative bodies can give regionally concentrated ethnic minorities more says. They can directly participate in politics and public administration and preserve their local ethnic identity better. As Schrottshmmer (2006) argues, this will avert demand for autonomy and secession. 
Besides the expected positive outcome of more effectiveness, another debate on the benefits of decentralization is centered on its conflict-resolving impact. Accordingly, decentralization supports to reduce conflict between ethnic group and secessionism by bringing the government closer to the people, increasing opportunities to participate in government, and ultimately giving groups control over their political, social and economic affairs. This control enables regions as well as ethnic groups clustered in religions to pass legislations protecting their various interests and concerns at the regional level governance. These interests and concerns may include: language protection, economic development, environmental policy, security and so forth. By enabling groups to protect their interests and concerns, decentralization prevents conflict among groups from fighting each other over what they perceive as unfair treatment by another group and reduce their incentive for region to seek their own independence status (Brancati, 2006:655-656). Transforming power and authority from central government to sub-national administrative and local government units and opening the political process to widespread participation provide an institutional framework for local autonomy and empower local communities to pursue local aspirations (Cheema \& Rondinelli, 2007).

If citizens believe that government is concerned and responsive to their needs, then citizens have recourse to reconcile their grievances. Similarly, if decentralization poster more space to exercise local customs and religious beliefs without fear of persecution, the risk of inter-group strife in ethnically diverse societies can be minimized (Siegle \& O'Mahony, 2009). Therefore, decentralization can be an institution that, if properly designed and potentially benefit both political minorities, who can be induced or compensated not to secede from the state, and political majorities, who gain countrywide acceptance of state institutions (Lake \& Rothchild, 2005).

The needs of local minority groups are more likely to be recognized within a devolved political system. Azar stresses that in protracted social conflicts highly centralized political structures are sources of conflict because they reduce the opportunity for a sense of community among groups, increase alienation and tend to deny to groups the means to accomplish their needs (Azar, 1986). Therefore, he proposed to abolish the centralized sovereign state and foster decentralized political systems. For conflicts to be enduringly resolved, appropriate decentralized structures are needed (Azar, 1986). As Diprose and Ukiwo (2008:4) indicate, decentralization has the potential to deflate national-level inter-group conflict for power, resources, and control, particularly in nations with diverse ethno-religious groups which are regionally concentrated. It can also improve contentious center-periphery relations, particularly when there is a history of protest against centralized rule and forms of cultural hegemony.

From the end of cold war, in post-conflict settings, decentralization is seen as a way to guard against one ethnic groups' (mostly majority or dominant group) attempt to reassert monopoly on state power. The domestic political logic of decentralization for stronger or more dominant groups in post-conflict contexts is that it signals to weaker parties a willingness to compromise and accommodate. This reassurance establishes a basis for transition towards peace, development and democratization process. At the same time, a dominant group's offer of decentralization could be interpreted as a sign of weakness and could provide a political platform for local leaders to compete for national political power or pursue secession. In many countries in transition, forms of decentralization of power appear to be helpful devices, bringing the state closer to the people and allowing ownership among citizens to govern and develop themselves. These devices allow people to express their needs more effectively and enable authorities to develop autonomy and deliver public services more efficiently.

An important argument for decentralization in post-conflict state reform, according to Linder (2009), is that people can better express their preferences for public goods and that local administrations can provide these goods for the local community more effectively than can central authorities. When power is shared vertically, the integration of segmented or even divided societies has a better chance to succeed. In smaller units, the chance of efficient governance and of sanctioning corruption seems to be higher. A quite different rational for decentralization is that it accommodates pressure for regional autonomy and, hence, perhaps increase legitimacy and sustainability of heterogeneous states (Litvack et al., 1998). Drick and Omer (2006:5) identify some key outcomes of decentralization in its process to deepen plural democracy, such as improved accountability and responsiveness to a broad range of citizens, improved skills and capacity of citizens to participate effectively in public affairs and new and expanded cadres of leaders with democratic skills that can transform the contestability of political markets.

Decentralization produces the outcome of improved service delivery by better matching of public services to citizens' needs and preferences and increased innovation, as problems are solved at the local level and as successes are disseminated. According to the democratization perspectives of decentralization, it is likely to empower further groups in places where the social order is inequitable in the extreme, and where severe exploitation and injustice are widespread. As Manor indicates it tends to erode winner-take-all attitudes which often wrought havoc across the developing world when open process are induced, in which multiple groups possess the political leverage to 
achieve some of their ends. People gain experience of political accommodations which do not allow any winner to take all. When leaders strengthened democratization and took firm actions to ensure conformity with democratic roles, local residents first become acquainted with the need for political accommodation (Manor, 2011).

However, it is noteworthy that Schou and Haug in their thoughtful review of literatures on decentralization, conclude that decentralization fulfills the conflict-mitigating role in a multi-ethnic society when it (i) broaden popular participation, including minority groups, (ii) bring sub-national groups into a bargaining process with the government, (iii) increases state legitimation through broadened local popular participation, (iv) establish state outreach and control in remote areas, (v) build trust between groups that participate local governance institutions, and (vi) redistribute resources between regions (Schou and Haug, 2005:29-30). Also, they identify the risks of decentralization in increasing conflict potential when it increases competition between local and national power holders. This may entail subnational actors using decentralized resources for political mobilization, including the capacity of groups to break away. In response to this, central government may attempt to regain transferred power and authority. Also decentralization may induce conflict between ethnic groups and regions when the central government's oversight become lacking, particularly in the reallocation of resources between regions (Schou and Haug, 2005:29-30).

Although there are negative arguments on ethnic accommodative role of centralization as it (i) encourages the promotion of ethnic, regional, and communal identities which lead to separatist mobilization, (ii) generates conflict by working against the entrenchment of democratic values, (iii) provide a sphere for domination of minority groups by majority groups at the local level, however, in many cases decentralization initiatives has been successful as affords to protect minority rights, and management of ethno-centric conflicts. The process of accommodation and empowerment of ethnic minority groups in many post-colonial and post-communist countries coincided with decentralization of many unitary democratic governments.

Many European experts find decentralization as an important way of improving the performance of the local governance and civil service toward interest accommodation of diverse groups. In most developing countries in Latin America, decentralization is often viewed as part of strengthening democratization process. In many Asian countries, decentralization initiatives were viewed as part of the process of improving public service delivery to large populations in the centralized countries. Also, in some Asian countries such as Indonesia, India and Sri Lanka, decentralization reforms considered as tool to accommodate the autonomy and self-determination claims of competing ethnic groups. Decentralization reforms have been pursued throughout Africa over the last 30 years with the aims of improving governance efficiency and making policy more responsive to the needs and claims of local people, particularly the diverse ethnic groups. But, the degree of decentralization in terms of power and autonomy granted to local units and regionally concentrated ethnic and linguistic groups also greatly varies among developing countries. From 1980s onwards, many developed and developing have moved toward more decentralized patters of governance to cope up with number of issues and problems emerged among diverse ethnic groups advocating for more powers, authority and autonomy. This has attracted the interests of scholars from various disciplines towards decentralization studies.

\section{Conclusion}

Decentralization initiatives has become a key element of political and administrative reforms in many countries for many reasons from 1980s onwards. Decentralization is seen as mechanism to strengthen democracy, empower autonomy, increase participation, enhance development and improve service delivery and so on at local level. In this way, conceptually, decentralization also has an ethnic diversity accommodative role. In plural or diverse societies, decentralization can help to redistribute resources, ensure the protection of rights of different groups, often minorities, can widen the participation of groups in decision-making and local and regional development process. Further, the decentralization of power among different groups of people who are separated along ethnic, religious, regional lines can resolve conflicts emerge based on political power sharing, resource distribution, and democratic participation. Since majority of the countries in the world are ethnically plural, in most of the countries managing aspirations of ethnically different groups, and accommodating their rights and interests within political and administrative machinery become challengeable. Therefore, in many plural states, the relationship between majority group and minority groups contesting and often lead to conflicts and cleavages and resulted on the domination of one group, mostly majority while discriminating and marginalizing other groups, mostly minorities in political decision-making and administrative affairs. In many plural states, especially in developing world, the projects of nation and state building were challenged due to the insufficient mechanism to incorporate interests of different groups and accommodate their due rights. In many of these countries, nation-building projects have supported or promoted to establish domination of majority groups in social and political life, and promoted to abolish features and identity of minority groups which prompted them to mobilize and advocate for groups-based 
rights and powers on their part.

There are many mechanisms to accommodate rights and interests of different groups in ethnically plural society. Decentralizing power and authority to sub-national governments and ethnic groups located territorially has also been identified as one of the best mechanisms among many on this regard. As viewed earlier, decentralization is defined as a process by which central state power is devolved or delegated, transferred or shared to sub-national units of governance to broaden access to political and administrative decision-making and localize provision of delivering public goods and services.

Conceptually, decentralization can also be identified as a positive tool for conflict reduction and ethnic cohesion in plural societies, by allowing the different groups to participate in the political and administrative affairs of not only in development process but also in every affair of local and regional governance. In this set-up, different groups of people will also be empowered and equally treated in local administration and policy oriented development. Therefore, decentralization advocates argue that decentralized governance is more responsive to the needs of the poor and minorities than central governance and thus more likely to conceive and implement pro-poor and all inclusive policies. In many parts of the world, especially in many developed countries, forms of decentralization have contributed in positive ways to accommodate interests and claims of ethnic groups, especially of minorities. However, in many developing countries, the decentralization experiences of accommodating rights, needs and interests of diverse groups within the larger political system have been a series of disappointed stories due to number of issues with regard to the development and implementation of decentralization policies and programs. In implementing process, the expected positive results of decentralization initiatives as to accommodate interests and claims of ethnic groups are needs to be examined carefully and they always depend on various aspects of the political and administrative contexts.

The common expectation with regard to ethnic diversity accommodative perspective of decentralization is that a decentralized system contributes to a better management of local problems and conflicts emerge among ethnic groups, based on the assumptions that those systems are, a) more efficient and respond to local needs, as local decision-makers are closer to the people, understand the their issues and make priorities between competing objectives and respond to local diversity and needs, b) more successful for poverty alleviation, c) create people-centered local administration, d) contribute to democratization through self-governance and e) create better options for the participation of different identity groups in terms of ethnicity, religious and regional concentration etc.

However, in the process of implementing decentralization, existing conflicts can be aggravated or new conflicts for power can be triggered between different groups. In post-conflict societies, the success of decentralization initiatives requires parallel strengthening of central and local capacities of governance and administration. The failure to do so will further weaken an already weak government and work against the restoration of ethnic integration and national unity. Also, sufficient dedication and ownership, matching of tasks, responsibilities and resources including the sufficient possibilities for all stakeholders for participation in the process of decentralization are important preconditions for the success of ethnic group accommodative perspectives of decentralization initiatives. Decentralization is not a formula in itself, but only makes sense in the context of an overall qualitative change in structures and institutions of state system in plural societies. Similarly, decentralization is neither a panacea for reducing conflict, demands and claims, nor a guarantee for the protection and empowerment of the rights and interests of ethnic groups. Therefore, for the success of ethnic diversity accommodative perspectives of decentralization, the formal understanding of the concept and its impacts, and the establishment of possible implementation mechanism are highly needed.

\section{References}

Ayenew, M. (1998). Some preliminary observations on institutional and administrative gaps in Ethiopia's decentralization processes. Addis Ababa: Addis Ababa University.

Brancati, D. (2006). Decentralization: Fueling the fire or dampening the flames of ethnic conflict and secessionism?. International Organization, 60, 651-685. http://dx.doi.org/10.1017/S002081830606019X

Brinkerhoff, D. W. (2005). Rebuilding governance in failed states and post-conflict societies: Core concepts and cross-cutting themes. Public Administration and Development, 25(1), 3-14. http://dx.doi.org/10.1002/pad.352

Cabral, L. (2011). Decentralisation in Africa: Scope, motivations and impact on service delivery and poverty. Brington: The Future Agricultures Consortium, University of Sussex.

Cheema, G. S., \& Rondinelli, D. A. (1983). Implementing decentralization policies: An introduction. In G. S. 
Cheema, \& D. A. Rondinelli (Eds.), Decentralization and development: Policy implementation in developing countries (pp. 9-34). New Delhi: Sage Publications.

Cheema, G. S., \& Rondinelli, D. A. (2007). From government decentralization to decentralized governance. In G. S. Cheema, \& D. A Rondinelli (Eds.), Decentralizing governance: Emerging concepts and practices (pp. 1-20). Washington D.C: Brooking Institute Press.

Conyers, D. (1983). Decentralization: The latest fashion in development administration. Public Administration and Development, 3(2), 97-109. http://dx.doi.org/10.1002/pad.4230030202

Conyers, D. (1999). Decentralization: A conceptual analysis. Paper presented at Ministers' Conference on Local Government in Eastern and Southern Africa, Victoria Falls, Zimbabwe. 21-23 September 1999.

Conyers, D. (2006). Decentralization: The latest fashion in development administration. In E. E. Otenyo, \& N. C. Lind (Eds), Comparative public administration: The essential readings, research in policy analysis and management (Vol. 15; pp. 447-462). Oxford: Radarweg. http://dx.doi.org/10.1016/S0732-1317(06)15019-8

Damayanthi, M. K. N. (2011). Devolution versus deconcentration: A study on land service delivery system in Sri Lanka. Master thesis. North-South University.

Diprose, R., \& Ukiwo, U. (2008). Decentralization and conflict management in Indonesia and Nigeria. Oxford: CRISE, University of Oxford.

Duncan, C. (2007). Mixed outcomes: the impact of regional autonomy and decentralization on indigenous ethnic minorities in Indonesia. Development and Change, 38(4), 711-733. http://dx.doi.org/10.1111/j.1467-7660.2007.00430.x

Esman, M. J. (1997). Public administration, ethnic conflict, and economic development. Public Administration Review, 57(6), 527-533. http://dx.doi.org/10.2307/976964

Faguet, J. P. (2013). Can subnational autonomy strengthen democracy in Bolivia?. Publius: The Journal of Federalism, 44(1), 51-81. http://dx.doi.org/10.1093/publius/pjt020

Faust, J., \& Harbers, I. (2011). On the local politics of administrative decentralization: Applying for policy responsibilities in Ecuador. Publius: The Journal of Federalism, 42(1), 52-77. http://dx.doi.org/10.1093/publius/pjq046

Gjoni, R., Wetterberg, A., \& Dunbar, D. (2010). Decentralization as a conflict transformation tool: The challenge in Kosovo. Public Administration and Development, 30, 291-312. http://dx.doi.org/10.1002/pad.577

Grasa, R., \& Camps, A. (2009). Conflict prevention and decentralized governance: Some remarks about the state of the art in theory and practice. Barcelona: International Catalan Institute for Peace.

Islam, M. T., \& Fujitha, K. (2012). Dimensions of decentralization process and rural local government in India: A comparison with Bangladesh. Kyoto: Kyoto University.

Kassahun, B., \& Tengegne, G. (2004). Citizen participation in the decentralization process in Ethiopia. Addis Ababa: The Ministry of Capacity Building.

Lake, D. A., \& Rothchild, R. (2005). Territorial decentralization and civil war settlement. In F. G. Roeder \& D. Ruthchild (Eds.), Sustainable peace: Power and democracy after civil wars (pp. 109-132). New York: Cornel University press.

Linder, W. (2009). On the merits of decentralization in young democracies. Polibius: The Journal of Federalism, 40(1), 1-30. http://dx.doi.org/10.1093/publius/pjp027

Litvack, J., Ahamed, J., \& Bird, B. (1998). Rethinking decentralization in developing countries. Washington D.C. World Bank. http://dx.doi.org/10.1596/0-8213-4350-5

Lyon, A. (2013). Between the integration and accommodation of ethnic differences: Decentralization in Republic of Macedonia. Journal of Ethnopolitics and Minority Issues in Europe, 11(3), 80-103.

Monteux, C. A. (2006). Decentralisation: The new delusion of ethnic conflict regulation? Democracy and Power-Sharing in Multi-National States, 8(2), 162-182.

Rolla, G. (1998). Autonomy: A guiding criterion for decentralizing public administration. International Review of Administrative Sciences, 64, 27-39. http://dx.doi.org/10.1177/002085239806400103

Rondinelli, D. A., McCullough, J. S., \& Johnson, R. W. (1989). Analyzing decentralization policies in developing countries: A political economy framework. Development and Change, 20(1), 57-87. 
http://dx.doi.org/10.1111/j.1467-7660.1989.tb00340.x

Schou, A., \& Haug, M. (2005). Decentralization in conflict and post-conflict situations. Oslo: Norwegian Institute for Urban and Regional Research.

Schrottshammer, E. (2006). Decentralization and conflict: a guide. Eschborn: GTC.

Scott, I. (1996). Changing concept of decentralization: Old public administration and new public management in the Asian context. Asian Journal of Public Administration, 18(1), 3-21. http://dx.doi.org/10.1080/02598272.1996.10800315

Smoke, P. (2003). Decentralisation in Africa: Goals, dimensions, myths and challenges. Public Administration and Development, 23(1), 7-16. http://dx.doi.org/10.1002/pad.255

Turner, M. (2006). From commitment to consequences: comparative experiences of decentralization in the Philippines, Indonesia and Cambodia. Public Management Review, 8(2), 253-272. http://dx.doi.org/10.1080/14719030600587471

\section{Copyrights}

Copyright for this article is retained by the author(s), with first publication rights granted to the journal.

This is an open-access article distributed under the terms and conditions of the Creative Commons Attribution license (http://creativecommons.org/licenses/by/3.0/). 